\title{
Synthesis and Crystal Structure of a Trigonally Compressed Hexakis-DMF Manganese(II) Complex
}

\author{
Ryo Suzuki, * Yukako Chiba, ${ }^{*}$ Ryo YAMAguchI, ${ }^{*}$ Daisuke Yoshioka, ${ }^{* *}$ Masahiro MikuriYa,** \\ and Hiroshi SAKIYAMA* $*$ \\ *Department of Material and Biological Chemistry, Faculty of Science, Yamagata University, \\ 1-4-12 Kojirakawa, Yamagata 990-8560, Japan \\ **Department of Chemistry and Research Center for Coordination Molecule-based Devices, School of Science \\ and Technology, Kwansei Gakuin University, Gakuen 2-1, Sanda 669-1337, Japan
}

\begin{abstract}
The manganese(II) complex $\left[\mathrm{Mn}(\mathrm{DMF})_{6}\right]\left(\mathrm{BPh}_{4}\right)_{2}[\mathrm{DMF}=N, N$-dimethylformamide $][$ hexakis $(N, N$-dimethylformamide$\kappa O$ )manganese(II) bis(tetraphenylborate)] was prepared, and characterized by a single-crystal X-ray method. The compound crystallizes in the triclinic space group $P \overline{1}$ and $Z=1$ with cell parameters: $a=10.0628(16) \AA, b=$

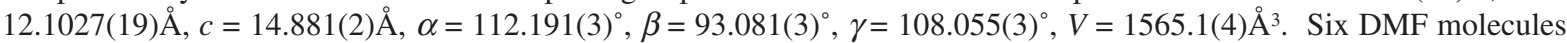
coordinate to a manganese(II) center to form a $\left[\mathrm{Mn}(\mathrm{DMF})_{6}\right]^{2+}$ cation, somehow approximated to an $S_{6}$ symmetry; however, the coordination geometry is apparently compressed along a pseudo-trigonal axis different from the $p s e u d o-S_{6}$ axis.
\end{abstract}

(Received December 23, 2012; Accepted February 6, 2013; Published on web March 10, 2013)

It is interesting to study how the coordination geometry is distorted around a central metal ion in coordination compounds, because the distortion influences the sign of the zero-field splitting, ${ }^{1}$ which is important in molecular magnetism; controlling the distortion leads to determining the magnetic behavior. The crystal structures of the hexakis-DMF nickel(II) complex $\left[\mathrm{Ni}(\mathrm{DMF})_{6}\right]\left(\mathrm{BPh}_{4}\right)_{2}$ and the hexakis-DMF cobalt(II) complex $\left[\mathrm{Co}(\mathrm{DMF})_{6}\right]\left(\mathrm{BPh}_{4}\right)_{2}[\mathrm{DMF}=N, N$-dimethylformamide $]$ were previously determined, ${ }^{2,3}$ and their crystal structures were found to be isomorphous to each other. Both complex cations are approximated to an $S_{6}$ symmetry, and trigonally compressed along the pseudo- $S_{6}$ axis. On the other hand, tetragonal compression was found only for the cobalt(II) complex. Since we wanted to reveal how the ligand field influences the distortion, in the present work we studied a high-spin manganese(II) derivative, which has no ligand field stabilization. It is a good example to observe the effect of the

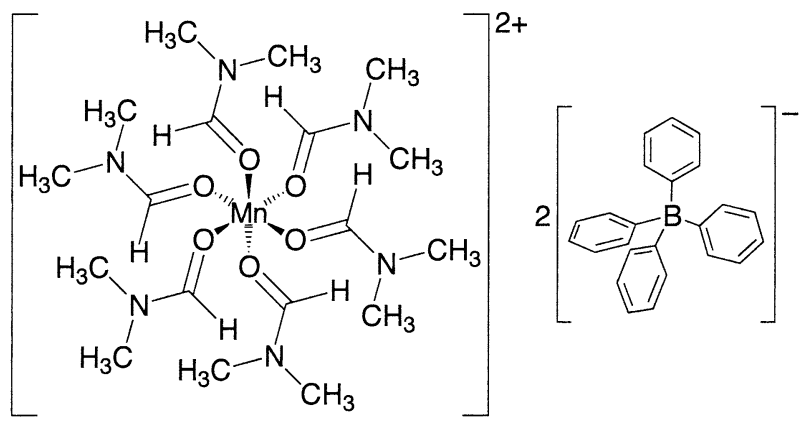

Fig. 1 Chemical structure of $\left[\mathrm{Mn}(\mathrm{DMF})_{6}\right]\left(\mathrm{BPh}_{4}\right)_{2}$.

† To whom correspondence should be addressed.

E-mail: saki@sci.kj.yamagata-u.ac.jp ligand field.

A manganese derivative, $\left[\mathrm{Mn}(\mathrm{DMF})_{6}\right]\left(\mathrm{BPh}_{4}\right)_{2}$, was prepared as follows: manganese(II) acetate tetrahydrate $(0.50 \mathrm{mmol}, 0.12$ g) was dissolved in DMF $(2.0 \mathrm{ml})$ and stirred for $0.5 \mathrm{~h}$ at room temperature; after the addition of a DMF solution of sodium tetraphenylborate $(1.00 \mathrm{mmol}, 0.34 \mathrm{~g})$, the solution was stirred for $1.5 \mathrm{~h}$, and the addition of water $(1.5 \mathrm{ml})$ resulted in the

Table 1 Crystal and experimental data

Chemical formula: $\mathrm{C}_{66} \mathrm{H}_{82} \mathrm{~B}_{2} \mathrm{MnN}_{6} \mathrm{O}_{6}$

Formula weight $=1131.94$

$T=90 \mathrm{~K}$

Crystal system: triclinic $\quad$ Space group: $P \overline{1}$

$a=10.0628(16) \AA$

$b=12.1027(19) \AA$

$c=14.881(2) \AA$

$V=1565.1(4) \AA^{3}$

$\alpha=112.191(3)^{\circ}$

$\beta=93.081(3)^{\circ}$

$\gamma=108.055(3)^{\circ}$

$Z=1$

$D_{\mathrm{x}}=1.201 \mathrm{~g} / \mathrm{cm}^{3}$

Radiation: Mo $K_{\alpha}(\lambda=0.71073 \AA)$

$\mu\left(\right.$ Mo $\left.K_{\alpha}\right)=0.266 \mathrm{~mm}^{-1} \quad F\left(\begin{array}{lll}0 & 0 & 0\end{array}\right)=603$

Crystal size $=0.55 \times 0.40 \times 0.35 \mathrm{~mm}^{3}$

No. of reflections collected $=9731$

No. of independent reflections $=6919[R$ (int $)=0.0153]$

$\theta$ range for data collection: 1.90 to $28.55^{\circ}$

Data/Restraints/Parameters $=6919 / 0 / 367$

Goodness-of-fit on $F^{2}=0.927$

$R$ indices $[I>2 \sigma(I)]: R_{1}=0.0389, w R_{2}=0.0881$

$R$ indices (all data): $R_{1}=0.0540, w R_{2}=0.0929$

$(\Delta / \sigma)_{\max }=0.001$

$(\Delta \rho)_{\max }=0.419 \mathrm{e}^{-3} \quad(\Delta \rho)_{\min }=-0.352 \mathrm{e}^{-3}$

Measurement: Bruker Smart APEX CCD diffractometer

Program system: SHELXTL

Structure determination: direct methods (SHELXS-97)

Refinement: full matrix least-squares (SHELXL-97)

CCDC deposition number: 916238 


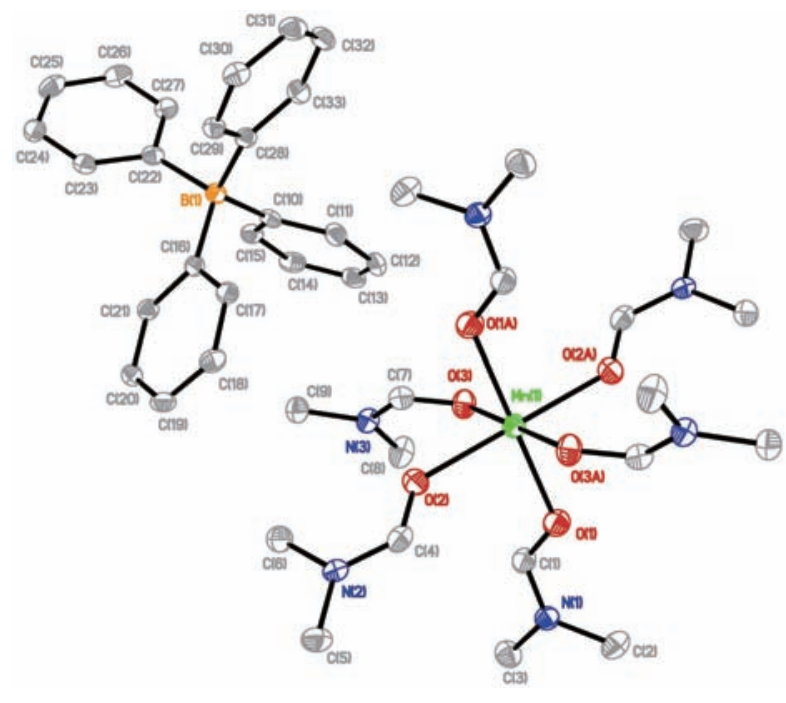

Fig. 2 Molecular structure of $\left[\mathrm{Mn}(\mathrm{DMF})_{6}\right]^{2+}$ and $\left(\mathrm{BPh}_{4}\right)^{-}$with atom labeling. Thermal ellipsoids are drawn at the $50 \%$ probability level, and hydrogen atoms are omitted for clarity.

precipitation of colorless microcrystals. Single-crystals suitable for X-ray analysis were obtained by slow diffusion of 2-propanol into a DMF solution of the complex.

The crystal data are included in Table 1. The structure was solved by direct methods and expanded using Fourier techniques. The non-hydrogen atoms were refined anisotropically, and hydrogen atoms were refined using the riding model. The final cycle of full-matrix least-squares refinement on $F^{2}$ was let to satisfactory converge with $R_{1}=$ $0.0389[I>2 \sigma(I)]$.

The crystal consists of complex cations, $\left[\mathrm{Mn}(\mathrm{DMF})_{6}\right]^{2+}$, and tetraphenylborate anions in a 1:2 molar ratio. The chemical structure and an ORTEP view are shown in Figs. 1 and 2, respectively. In the complex cation, six DMF molecules coordinate to a manganese(II) ion to form an octahedral geometry. To our knowledge, only two examples of such a structure were reported for $\left[\mathrm{Mn}(\mathrm{DMF})_{6}\right]\left[\mathrm{Mo}_{6} \mathrm{Br}_{6}\right](\mathrm{NCS})_{6}{ }_{6}$ and $\left[\mathrm{Mn}(\mathrm{DMF})_{6}\right]\left[\mathrm{Fe}_{2} \mathrm{Cl}_{6} \mathrm{O}\right] .{ }^{5}$ When we look at the bond distances around the central manganese(II) ion (Tables 2 and $3 \mathrm{~S}$ ), we find no tetragonal distortion around the octahedral $\mathrm{MnO}_{6}$ core; the deviation from the averaged distance is less than $0.3 \%$ (Table 2). On the other hand, when we focus on the bond angles around the manganese ion, a distinct trigonal compression is observed (Table 3S); the top and bottom angles, $\mathrm{O}(1)-\mathrm{Mn}(1)-\mathrm{O}(3), \mathrm{O}(1)-$ $\mathrm{Mn}(1)-\mathrm{O}(2 \mathrm{~A})$, and $\mathrm{O}(2)-\mathrm{Mn}(1)-\mathrm{O}(3 \mathrm{~A})[90.57(4)-95.10(4) \AA]$, are larger than $90^{\circ}$, whereas the side angles, $\mathrm{O}(1)-\mathrm{Mn}(1)-\mathrm{O}(2)$, $\mathrm{O}(1)-\mathrm{Mn}(1)-\mathrm{O}(3 \mathrm{~A})$, and $\mathrm{O}(2)-\mathrm{Mn}(1)-\mathrm{O}(3)$ [84.90(4) - 89.43(4) $\AA]$, are smaller than $90^{\circ}$; the edge distances around the top face, $\mathrm{O}(1) \cdots \mathrm{O}(2 \mathrm{~A}), \mathrm{O}(1) \cdots \mathrm{O}(3)$, and $\mathrm{O}(3) \cdots \mathrm{O}(2 \mathrm{~A})$ [3.085 - $3.197 \AA]$, are larger than the other edge distances, $\mathrm{O}(1) \cdots \mathrm{O}(2), \mathrm{O}(2) \cdots \mathrm{O}(3)$, and $\mathrm{O}(3) \cdots \mathrm{O}(1 \mathrm{~A})[2.924-3.054 \AA]$; distances between the opposite faces in the $\mathrm{MnO}_{6}$ core also indicate that one of the pair is more than $4 \%$ shorter than the average (Table 2). The direction of the trigonal compression is described in Fig. 3S. In the nickel(II) and cobalt(II) complexes, the whole structures of the hexakis-DMF cations were approximated to an $S_{6}$ point group, and the unit is trigonally compressed along the unique pseudo- $S_{6}$ axis. In the case of the present $\left[\mathrm{Mn}(\mathrm{DMF})_{6}\right]^{2+}$ cation, the structure can be somehow approximated as an $S_{6}$ point group (Fig. 3S), but the direction of the trigonal compression is different from the pseudo- $S_{6}$ axis.
Table 2 Distances between the opposite vertices and between the opposite faces

\begin{tabular}{|c|c|c|c|c|c|}
\hline Atom & Atom & Distance $(\AA)$ & \multicolumn{2}{|c|}{$\operatorname{Deviation}^{\mathrm{a}}(\AA)$} & Deviation $^{\mathrm{a}}(\%)$ \\
\hline $\mathrm{O}(1)$ & $\mathrm{O}(1 \mathrm{~A}$ & 4.3418 & \multicolumn{2}{|c|}{+0.0065} & +0.15 \\
\hline $\mathrm{O}(2)$ & $\mathrm{O}(2 \mathrm{~A}$ & 4.3412 & \multicolumn{2}{|c|}{+0.0059} & +0.14 \\
\hline $\mathrm{O}(3)$ & $\mathrm{O}(3 \mathrm{~A}$ & 4.3230 & \multicolumn{2}{|c|}{-0.0123} & -0.28 \\
\hline \multicolumn{2}{|c|}{$\begin{array}{l}\text { Triangular } \\
\text { face }\end{array}$} & $\begin{array}{l}\text { Triangular } \\
\text { face }\end{array}$ & $\begin{array}{l}\text { Distance }^{b} \\
(\AA)\end{array}$ & $\begin{array}{c}\text { Deviation } \\
(\AA)\end{array}$ & $\begin{array}{c}a^{c} \text { Deviation }^{\mathrm{c}} \\
(\%)\end{array}$ \\
\hline \multicolumn{2}{|c|}{$\mathrm{O}(1)-\mathrm{O}(2)-\mathrm{O}(3)$} & $O(1 A)-O(2 A)-O(3 A)$ & ) 2.562 & +0.060 & +2.41 \\
\hline \multicolumn{2}{|c|}{$\mathrm{O}(1)-\mathrm{O}(2)-\mathrm{O}(3 \mathrm{~A})$} & $O(3)-O(1 \mathrm{~A})-\mathrm{O}(2 \mathrm{~A})$ & 2.460 & -0.042 & -1.69 \\
\hline \multicolumn{2}{|c|}{$O(2)-O(3)-O(1 A)$} & $O(1)-O(2 A)-O(3 A)$ & 2.590 & +0.089 & +3.54 \\
\hline \multicolumn{2}{|c|}{$O(1)-O(3)-O(2 A)$} & $\mathrm{O}(2)-\mathrm{O}(1 \mathrm{~A})-\mathrm{O}(3 \mathrm{~A})$ & 2.395 & -0.107 & -4.26 \\
\hline
\end{tabular}

aDeviation from the average distance (4.3353 $\AA$ ).

bistance between the middle points of the triangular faces at the opposite positions.

'Deviation from the average distance (2.502 $\mathrm{A})$.

If we compare the structural feature of the $\left[\mathrm{Mn}(\mathrm{DMF})_{6}\right]^{2+}$ cation with those of the $\left[\mathrm{Co}(\mathrm{DMF})_{6}\right]^{2+}$ and $\left[\mathrm{Ni}(\mathrm{DMF})_{6}\right]^{2+}$ cations, the tetragonal distortion of the manganese derivative is the smallest, $\left[\mathrm{Mn}_{\text {tet }}(0.3 \%)<\mathrm{Ni}_{\text {tet }}(0.5 \%)<\mathrm{Co}_{\text {tet }}(0.8 \%)\right]$, which is consistent with the $d^{5}$ electron configuration without the ligand field stabilization. The tetragonal compression for the cobalt derivative ${ }^{3}$ is understandable based on the anisotropically filled $t_{2 \mathrm{~g}}$ orbital. If we compare the trigonal compression among the compounds, the manganese derivative is the largest, $\left[\mathrm{Mn}_{\mathrm{tri}}\right.$ $\left.(4.3 \%)>\mathrm{Ni}_{\text {tri }}(3.0 \%)>\mathrm{Co}_{\text {tri }}(2.7 \%)\right]$; this means that the manganese derivative is the most flexible because of a lack of the ligand field stabilization. It is also interesting to discover the following relationship: the smaller is the tetragonal distortion, the larger is the trigonal compression.

In the present crystal, the $\left[\mathrm{Mn}(\mathrm{DMF})_{6}\right]^{2+}$ cation is perfectly surrounded by eight tetraphenylborate anions, which are attracted to the complex cation by $\mathrm{CH} \cdots \pi$ interactions.

In conclusion, the present $\left[\mathrm{Mn}(\mathrm{DMF})_{6}\right]^{2+}$ complex cation can be somehow approximated to the $S_{6}$ point group; however, the coordination geometry is trigonally compressed along a pseudotrigonal axis different from the pseudo- $S_{6}$ axis.

\section{Supporting Information}

A CIF format file, Table 3S, and Fig. 3S. These materials are available free of charge on the Web at http://www.jsac.or.jp/xraystruct/.

\section{References}

1. R. Boča, Coord. Chem. Rev., 2004, 248, 757.

2. R. Yamaguchi, M. Yamasaki, and H. Sakiyama, X-ray Struct. Anal. Online, 2011, 27, 71.

3. K. Abe, Y. Chiba, D. Yoshioka, R. Yamaguchi, M. Mikuriya, and H. Sakiyama, X-ray Struct. Anal. Online, 2012, 28, 65 .

4. V. A. Khutornoi, N. G. Naumov, Yu V. Mironov, O. Oeckler, A. Simon, and V. E. Fedorov, Koord. Khim., 2002, 28, 183.

5. E. N. Chygorin, S. R. Petrusenko, V. N. Kokozay, Y. O. Smal, I. V. Omelchenko, O. V. Shishkin, Acta Cryst., 2011, E67, m1563. 